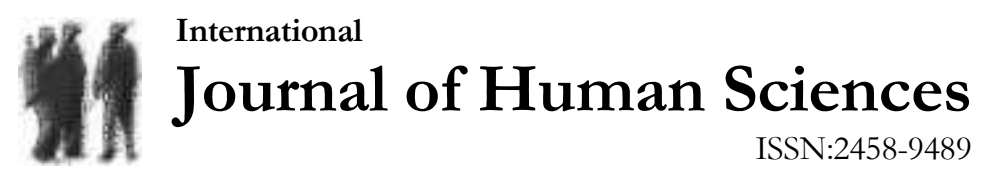

Volume 16 Issue 2 Year: 2019

\section{Adoption factors to digital TV platforms in Turkey ${ }^{1}$}

\author{
Burçin Yersel $^{2}$
}

\begin{abstract}
The main aim of this study is to understand digital TV platform adopters' media usage and adopting factors by identifying their profile in Turkey. According to this aim, it was tried to find out the demographic characteristics of digital TV broadcasting adopters, media usage level and the factors of adopting. In addition, it was tried to find out demographic variables, media usage frequency differences between adopters of digital TV platform and non-adopters. The result of analysis shows that, while it was found significant differences between adopters' and non-adopters' education; was not found significant differences between adopters' and non-adopters' age and sex. There is no significant differences between adopters' and non-adopters' media uses. According to the results of factor analysis shows that there are 5 reason to adopting digital TV platform.
\end{abstract}

Keywords: Technologic adoption; new media; digital broadcasting; interactive TV; digital TV platforms.

\section{Introduction}

Nowadays, digital technology is all around our daily life. The life is changing together in the same speed with the technology. Most of the people in the world lives mobile. New facilities and opportunities like interaction, easiness and speed bring given to people by digital mobile technologies. Although the television seems like traditional media it had a big convergence with digital technology. Since 2000 we have able to place television in the new media category. Although the rapid change of the technology television can able to keep its popularity in households. Television as a new media gave new opportunities to the viewers. Swedlow (2006) argues that by the digital television broadcasting, television transformed into more participant, using for more infotainment, nonlinear, focus more advertising, and two-way information platform. Television is positioned as a device that is used for information and communication by the viewer. Interaction in the television defined as new TV viewing experience that viewer able to control over what, when and how he/she watch or actively participate the program (Jensen, 2001, p.352). In Turkey, digital television broadcasting started delivering programs to the viewer via digital platforms at beginning of 2000's. late of 2010's digital platform broadcasting diffused by different suppliers. With digital platforms, facilities such as interactivity, the watching ability of coded programs can be served to

1 The study is an expanded version of the paper, which was prepared from the $\mathrm{PhD}$ thesis titled "Digitalization in information age and adoption to the new technology: The case of digital television broadcasting in Turkey" which was accepted by the Social Sciences Institute of the Anadolu Universities in 2008, and presented at the $22^{\text {nd }}$ Annual Conference of International Academy of Business Disciplines (IABD) 2010.

2 Associate Professor, Eskişehir Tecnical University, Porsuk Vocational Highschool. , bispir@eskisehir.edu.tr

Submitted: 05/03/2019 Published: 08/04/2019 
Yersel, B. (2019). Adoption factors to digital TV platforms in Turkey. Journal of Human Sciences, 16(2), 469-476. doi:10.14687/jhs.v16i2.5696

the subscribers. The digital platform subscribers' experiences and perception which determines transforming from analog TV broadcasting to digital broadcasting, will effect diffusion of this broadcasting technology.

\section{Early majority of digital TV platform subscribers}

The special features of digital TV platforms gives new dimensions uses and positions of TV as an interactive mass communication vehicle. However it's not well known how the special features of digital TV broadcasting will affect existence of this new technology. Because the thoughts of people, who are the first user of new technology and known as "critical mass", are an important factor define the life of new technology. The first studies about adoption and diffusion of new technologies was done by Everett M. Rogers. The theory of "diffusion of innovation" of Rogers is an area of communication studies which try to explain how the new technologies adopting by the people and how innovations diffusing in the society (Mutlu, 1998, p.371). Diffusion of innovation theory explains how the users moved the new technologies to the others, evaluated new technologies and adopted (Kang, 2002: 1995). Diffusion of innovations theory that foregrounds technology and ideology was introduced by Rogers and Shoemaker in 1973. Rogers revised the theory according to the new communication technology in 1995 and argues five stages for innovation decision process: Knowledge, persuasion, decision, implementation and confirmation (Rogers, 2003, p.169).

Diffusion of innovation speed is important factor for diffusion of new technology. Because the factors that affect diffusion of innovation speed, also affects the ratio of adoption of innovation. These factors are relative advantage, compatibility, complexity, trialability and observability. Receivers adopt an innovation in a short time if the innovation has more relative advantage, compatibility, complexity, trialability and observability than the others (Mahler and Rogers, 1999, p.723). Rogers (2003, p.279) define five adopter categories in the innovation of diffusion theory. These are innovators, early adopters, early majority, late majority, laggards. Individuals in these categories differ from others according to their various characteristics (Kang, 2002 , p.196). The criterion for adopter categorization is innovativeness, the degree to which an individual or other unit of adoption is relatively early in adopting new ideas than other members of social system (Rogers, 2003, p.280). According to Rogers (2003, p.281) $2.5 \%$ of individuals in a system are innovators, $13.5 \%$ of individuals are early adopters, $34 \%$ of individuals are early majority, $34 \%$ of individuals are late majority and $16 \%$ of individuals are laggards.

Demographic characteristics such as personality, education, social economic status, age, etc. of individuals in these categories differ from each other. For example, while late majority can be defined as individuals who have low income, more conservative, negative attitudes toward new technologies, innovators can be defined as individuals who have more income, curious, positive attitudes toward new technologies (Rogers, 2003, p.281-283; Dupagne, 1999, p.40). Studies about diffusion of innovation focused mostly characteristics of individuals who tend to adopt new technology. Diffusion of innovation theory defines adopters of new media as more daring, less dogmatic, and more risk taken individuals in order to satisfy their self-needs (Atkin et al, 2003, p.162).

The studies based on adopter categories of Rogers focused on innovators and early majority. Innovators are passionate lover of technology and adopt new technology for their enjoyment. We can define innovators as a passionate lover of technology who is the first adopter of the new technology. Early majority is curious adopters following innovators. Early majority group determine the continuity of the product (Chan-Olmsted at al. 2005, p.331). Demographic characteristics and media usage behavior was investigated as a predictor of new media adoption in the new technology adoption studies. In these studies generally independent variables are demographic variables, media usages, technology ownership, adoption need, and satisfaction, depended variable is adoption categories (Chan-Olmsted at al. 2005, p.328). 
Yersel, B. (2019). Adoption factors to digital TV platforms in Turkey. Journal of Human Sciences, 16(2), 469-476. doi:10.14687/jhs.v16i2.5696

\section{Digital TV platform broadcasting and viewers in Turkey}

Digital TV platform broadcasting can be called as new communication technology in Turkey. Digital platform subscribers' penetration rate was 7\% (2010) and now its \% 41 (2018). In 2010 there was only one digital broadcasting platform but in 2018 there are 8 digital tv broadcasting and IPTV platforms. Different channels and interactivity opportunities are given to the subscribers. With the name of "The Digital Eyes of Turkey" research which was made by Twentify shows some media usage and demographic results about digital tv platform subscribers. According to the research on digital tv platform subscribers in Turkey shows that social economic status are effective variables on adoption process. $\% 61$ of the subscribers have higher social economic status. According to this research shows that the content of the broadcasting platform and channels are effective variables for choosing the subscription of a platform. Sex is not an effective variable for using this technology. In 2012 while viewers were watching 222 minutes, in the year of 2017, 330 minutes were watched on tv. According to new and mobile technology watching tv is an involuntary attitude in Turkey. Nowadays when we look to the penetration rate we can say that these subscribers can be called as early majority. Digital platform subscribers' perception about this diffusing technology, also these subscribers can be called as critical mass; will determine the future of this broadcasting technology in Turkey.

\section{Methodology}

The main aim of this study is to understand digital TV broadcasting adopters' media usage and adoption factors by identifying their profile in Turkey. According to this aim, following research questions was determined.

- What are the demographic profiles (age, sex, education) of digital TV platform adopters?

- Are there any significant differences between demographic profiles of digital TV broadcasting adopters and demographic profiles of non-adopters?

- Are there any significant differences between media usage frequency of digital TV broadcasting adopters and media usage frequency of non-adopters?

- What are the adopting factors of digital TV platform adopters?

Respondents were selected with systematic random sampling technique from the Anadolu University workers. Survey was distributed 819 respondents via mail. 513 surveys returned. Response rate is $63 \%$. Survey has three parts. In the first part, demographic variables (age, sex, education) were collected. Age is continuous variable; sex and education categorical variable. The second part of the survey includes media usage level. In this stage TV watching, newspaper and magazine reading, uses of internet, and movie going frequency were asked. The third part of survey includes a scale to find out the factors of adoption.

In order to statistical analysis a new nominal variable was created by coding digital platform subscribes as adopters and non-subscribers as non-adopters. The category named adopters coverage innovators, early adopter and early majority of Rogers' adoption category. The category named non-adopters coverage late majority and laggards. For the statistical tests, T-test, independence chi-square test and Principles Component Factor analysis was used according to the variable type.

\section{Results}

The mean of age is 33.5 for adopters and 32.1 for non-adopters. To find out difference between adopter and non-adopter according to the age, T-test was used. The T-test results can be seen in Table 1. T-test results show that while there is no significant difference between mean of adopters' age and non-adopters. 
Yersel, B. (2019). Adoption factors to digital TV platforms in Turkey. Journal of Human Sciences, 16(2), 469-476. doi:10.14687/jhs.v16i2.5696

Table 1. T- test results between adopters and non-adopters according to the age

\begin{tabular}{rlcccc}
\hline Variable & Adopting categories & $\mathbf{N}$ & Mean & $\mathbf{t}$ & $\mathbf{p}$ \\
\hline \multirow{2}{*}{ Age } & Adopters & 99 & 33.54 & \multirow{2}{*}{1.548} & \multirow{2}{*}{0.124} \\
\hline \hline
\end{tabular}

${ }^{*} \mathrm{p}<0,05$

$64 \%$ of adopters are women, $36 \%$ of male. $53 \%$ of non-adopters are women, $47 \%$ of are male. Chi-square independence test was used to find out differences between adopters and nonadopters according to the sex. According to the chi-square test results there is no significant relationship between adopters' sex and non-adopters' sex $\left(\mathrm{X}^{2}=3.519, \mathrm{df}=1 \mathrm{p}>0.01\right)$. Additionally, Chi-square independence test was used to find out differences between adopters and non-adopters according to the education. According to the chi-square test results there is significant relationship between adopters' education and non-adopters' education $\left(\mathrm{X}^{2}=40.310 ; \mathrm{df}=5 ; \mathrm{p}<0.01\right)$. Adopters more educated than non-adopters.

The average weekday TV viewing time of adopters is 2.8 hours and the average weekday TV viewing time of non-adopters is 2.9 hours. The average weekend TV viewing time of adopters is 4.1 hours and the average weekend TV viewing time of non-adopters is 4.4 hours. According to the T-test result which was done to the find out differences between weekday-weekend TV viewing time of adopters and non-adopters, there is no significant difference between adopters and nonadopters (Table 2).

Table 2. T-tests result between weekday-weekend tv viewing time of adopters and non-adopters

\begin{tabular}{|c|c|c|c|c|c|}
\hline Variable & $\begin{array}{c}\text { Adopting } \\
\text { categories }\end{array}$ & $\mathbf{N}$ & Mean & $\mathbf{t}$ & $\mathbf{p}$ \\
\hline \multirow{2}{*}{ Weekday TV viewing time } & Adopters & 99 & 2.85 & \multirow{2}{*}{-0.4929} & \multirow{2}{*}{0.622} \\
\hline & Non-adopters & 408 & 2.94 & & \\
\hline \multirow{2}{*}{ Weekend TV viewing time } & Adopters & 99 & 4.14 & \multirow{2}{*}{-11.485} & \multirow{2}{*}{0.252} \\
\hline & Non-adopters & 408 & 4.47 & & \\
\hline
\end{tabular}

Average internet usage time of adopters is 4.6 hours in a day and average internet usage time of non-adopters is 3.86 hours in a day. According to the T-test result which was done to the find out differences between daily internet usage time of adopters and non-adopters, there is significant difference between adopters and non-adopters (Table 3). In other word adopters are using internet mostly.

Table 3. T-test result between daily internet usage time of adopters and non-adopters

\begin{tabular}{|l|l|c|c|c|c|}
\hline Variable & $\begin{array}{l}\text { Adopting } \\
\text { categories }\end{array}$ & $\mathbf{N}$ & Mean & $\mathbf{t}$ & $\mathbf{p}$ \\
\hline \multirow{2}{*}{ Daily internet usage time } & Adopters & 99 & 4.6 & 25.334 & $0.012^{*}$ \\
\cline { 2 - 5 } & Non-adopters & 408 & 3.8 & &
\end{tabular}

${ }^{*} \mathrm{p}<0,05$

Average movie going time of adopters is 1.1 days in a month and Average movie going time of non-adopters is 1.1 days in a month. According to the average movie going times, it's possible to say that there is no difference between movie going time of adopters and non-adopters. The mean of newspaper reading in a week is 5.1 day for adopters and 2.5 day for non-adopters. The mean of magazine reading in a week is 1.6 day for adopters and 1 day for non-adopters. $4 \%$ of adopters and $7.8 \%$ of non-adopters are never reading a newspaper in a week. $27.3 \%$ of adopters and $50.2 \%$ of non-adopters are never reading magazine in a week. 
Yersel, B. (2019). Adoption factors to digital TV platforms in Turkey. Journal of Human Sciences, 16(2), 469-476. doi:10.14687/jhs.v16i2.5696

To find out difference between newspaper-magazine reading mean of adopters and nonadopters, T-test was used. According to the T-test results, there is significant difference between adopters' newspaper-magazine reading mean and non-adopters' newspaper-magazine reading mean (Table 4). Adopters read more newspaper and magazine than non-adopters.

Table 4. T-test results between newspaper-magazine reading mean of adopters and non-adopters

\begin{tabular}{|l|l|c|c|c|c}
\hline \multicolumn{1}{c|}{ Variable } & Adopting categories & $\mathbf{N}$ & Mean & $\mathbf{t}$ & $\mathbf{p}$ \\
\hline \multirow{2}{*}{ Newspaper } & Adopters & 99 & 5.1 & \multirow{2}{*}{2.598} & \multirow{2}{*}{$0.010^{*}$} \\
\cline { 2 - 6 } & Non-adopters & 408 & 4.5 & & \\
\multirow{2}{*}{ Magazine } & Adopters & 99 & 1.6 & \multirow{2}{*}{3.235} & $0.000^{*}$ \\
\cline { 2 - 6 } & Non-adopters & 408 & 1.0 & & \\
\hline
\end{tabular}

${ }^{*} \mathrm{p}<0,05$

A scale of 22 expressions was used to demonstrate the reasons for adoption. factor analysis (Principal Component Factor) was conducted to group, classify these 22 expressions and to determine the main factors causing adaptation.

Bartlett's and KMO tests were performed to determine whether the data set was appropriate for factor analysis (Table 5). According to the results of the tests, the KMO value is above 0,50 and the Bartlett test is also significant $(\mathrm{p}<0,05)$.

Table 5. Results of the KMO and Bartlett's Tests

\begin{tabular}{lccc}
\hline \hline Kaiser-Meyer-Olkin & \multicolumn{3}{c}{ Bartlett's Test } \\
\hline \multirow{2}{*}{0,70} & Chi-Square & sd & $\mathrm{P}$ \\
& 621,72 & 153 & $0,000^{*}$ \\
\hline \hline${ }^{\mathrm{p}}<0,05$ & &
\end{tabular}

In the factor analysis, it is recommended to remove the statements with common variance below 0,50 from the analysis (Kalayc1, 2006, p.329). As a result of the first analysis, the common variances of the 22 statements were examined and the statements of 4, 12, 19 and 22 having a common variance below 0,50 were removed from the analysis. Second factor analysis was conducted over 18 statements.

In factor analysis, the substances are asked to have high load value in one factor and low load value in other factors. It is desired that a substance (statement) it gives a load value with a second factor other than a factor it gives a high load value is not less than 0,10 (Büyüköztürk, 2002, p.119). Based on this criterion, since the difference between the loads the 1st statement gives in the first and sixth factors is 0,05 and the difference between the loads the 5th statement gives in the second and third factors is 0,04 , these statement was also removed from the analysis. At this stage, third analysis was conducted over 16 statements.

As a result of the third analysis, the 17 th statement having a common variance below 0,50 was also removed from the analysis and at the final analysis, five factors were obtained as adaptation to digital television broadcasts (Table 6). 
Yersel, B. (2019). Adoption factors to digital TV platforms in Turkey. Journal of Human Sciences, 16(2), 469-476. doi:10.14687/jhs.v16i2.5696

Table 6. Factors related to reasons for adaptation

\begin{tabular}{|c|c|c|c|c|c|c|}
\hline Statement & Factors & COM. & $\begin{array}{l}\text { Factor } \\
\text { Loads }\end{array}$ & Value & $\begin{array}{l}\% \text { of the } \\
\text { Variance } \\
\text { Explained }\end{array}$ & Alpha \\
\hline & Interaction Opportunity & & & \multirow{5}{*}{4,36} & \multirow{5}{*}{29,05} & \multirow{5}{*}{0,79} \\
\hline 15 & $\begin{array}{l}\text { Because I can make transactions such as } \\
\text { Banking, Shopping, Stock Market from } \\
\text { television }\end{array}$ & 2,17 & 0,82 & & & \\
\hline 7 & $\begin{array}{l}\text { Because it can provide interaction } \\
\text { opportunity }\end{array}$ & 2,94 & 0,76 & & & \\
\hline 6 & $\begin{array}{l}\text { Because it broadcasts the Turkish football } \\
\text { league }\end{array}$ & 2,70 & 0,72 & & & \\
\hline \multirow[t]{2}{*}{8} & For watch\&pay system (Movie halls) & 2,70 & 0,63 & & & \\
\hline & Near Environment and Self & & & \multirow{5}{*}{1,96} & \multirow{5}{*}{13,07} & \multirow{5}{*}{0,73} \\
\hline 2 & $\begin{array}{l}\text { Because everyone around me has } \\
\text { subscribed }\end{array}$ & 1,99 & 0,85 & & & \\
\hline 3 & \multirow{2}{*}{$\begin{array}{l}\text { Because my friends recommend it } \\
\text { To be able to follow the programs that } \\
\text { everyone watches }\end{array}$} & 2,41 & 0,79 & & & \\
\hline 13 & & 2,14 & 0,61 & & & \\
\hline 11 & $\begin{array}{l}\text { Having a digital platform will make me } \\
\text { privileged } \\
\text { Channel Numerousness }\end{array}$ & 2,12 & 0,57 & & & \\
\hline 9 & Since many channels are available & 3,45 & 0,88 & \multirow[t]{2}{*}{1,46} & \multirow[t]{2}{*}{9,71} & \multirow[t]{2}{*}{0,69} \\
\hline \multirow[t]{2}{*}{16} & To be able to watch the latest movies & 3,25 & 0,72 & & & \\
\hline & Foreign Language Selection Option & & & \multirow{3}{*}{1,35} & \multirow{3}{*}{9,02} & \multirow{3}{*}{0,73} \\
\hline 20 & $\begin{array}{l}\text { Since international channels broadcasting in } \\
\text { a foreign language are available }\end{array}$ & 3,80 & 0,88 & & & \\
\hline \multirow[t]{2}{*}{21} & $\begin{array}{l}\text { Because language selection option is } \\
\text { available }\end{array}$ & 3,84 & 0,86 & & & \\
\hline & Following Technology & & & \multirow{4}{*}{1,01} & \multirow{4}{*}{6,76} & \multirow{4}{*}{0,62} \\
\hline 10 & $\begin{array}{l}\text { Because I want to follow the new } \\
\text { technology }\end{array}$ & 3,13 & 0,73 & & & \\
\hline 14 & $\begin{array}{l}\text { Since all broadcasting will be digital in the } \\
\text { near future }\end{array}$ & 2,76 & 0,61 & & & \\
\hline 18 & $\begin{array}{l}\text { Because there are channels for children (Specific } \\
\text { Factor) }\end{array}$ & 3,03 & $-0,59$ & & & \\
\hline & Total Explained V ariance & & & & 67,62 & \\
\hline
\end{tabular}

As a result of the analysis, 5 factors whose values were greater than 1 were found as the reason of adaptation. These 5 factors explain $67,6 \%$ of the total variance. It can be stated that the percentage of total variance explained by the five factors resulting from factor analysis is high.

When Table 6 is examined, the first factor given as a reason of adaptation consists of four variances and is named as "interaction opportunity", the second consists of four variances and is named as "near environment and self", the third consists of two variances and is named as "channel numerousness", the fourth consists of two variances and is named as "foreign language selection option" and the fifth consists of three variances and is named as "following technology". The reliability coefficient for each factor (Cronbach-alpha) ranges between 0,79 and 0,62. Depending on the Alpha coefficient, if it is $0,60 \leq \alpha \leq 0,80$ the scale is interpreted as highly reliable (Kalayc1, 2006, p.405). Accordingly, the reliability coefficients for each factor are acceptable.

When Table 6 is examined, the point that should be considered is that the factor load of the 18 th factor is negative. Negative and small factor loaded statements can mean specific factor. These factor loads are loaded with other specific information other than the common factor (S.encan, 2005, p.393). The 18th statement was considered to be a specific factor due to the fact that it is negative loaded with a small factor and it does not comply with the fifth factor considering the 
Yersel, B. (2019). Adoption factors to digital TV platforms in Turkey. Journal of Human Sciences, 16(2), 469-476. doi:10.14687/ihs.v16i2.5696

meaning it has. In other words, the fact that there are channels for children as the reason for nonadaptation is a specific factor.

Validity and reliability tests of the structures obtained as a result of factor analysis are required. Reliability measurements were made using Cronbach's Alpha coefficients. Alpha was calculated as 0,80 for 15 variables subjected to the factor analysis at the scale. Alpha reliability coefficient was found to be 0,79 for the first factor; 0,73 for the second factor; 0,69 for the third factor; 0,73 for the fourth factor and 0,62 for the fifth factor Depending on the Alpha coefficient; if it is $0,60 \leq \alpha \leq 0,80$, the scale is interpreted as pretty reliable (Kalayc1, 2006, p.405). Accordingly, the reliability coefficients for each factor are acceptable.

Convergent validity and discriminant validity tests were performed as validity tests. Bagozzi and Yi (1988) show that the factor loads of the statements exceed 0,70 as a proof of the validity of the adaptation. For Child (1970), the factor load factor of 0,50 and above is considered to be sufficient for the validity of the adaptation. When the factor loads of the statements in Table 6 are examined, it can be seen that these factor loads have acceptable levels of adaptation validity on desired structures.

The discriminancy validity refers to the adequate degree of discriminancy of measurements in different structures from other structures. It is requested that the binary correlation values between the factors for discriminancy validity should not exceed the critical value of 0,90 (Hair, Anderson and Tatham, 1998). When the correlation coefficients of the structures in Table 7 are examined, it is seen that the values are below 0,90. Accordingly, it can be said that the scale has a discriminancy validity.

Table 7. Correlation matrix and averages between factors of reason for adaptation

\begin{tabular}{llllll}
\hline \multicolumn{1}{c}{ Factors } & 1 & 2 & 3 & 4 & 5 \\
\hline Interaction Opportunity & 1,00 & & & & \\
Near Environment and Self & $0,39^{* *}$ & 1,00 & & & \\
Channel Numerousness & $0,45^{* *}$ & $0,29^{* *}$ & 1,00 & & \\
Language Selection & 0,11 & $-0,04$ & 0,22 & 1,00 & \\
Following Technology & $0,49^{* *}$ & $0,27^{* *}$ & $0,46^{* *}$ & $0,21^{*}$ & 1,00 \\
\hline${ }^{*} \mathrm{p}<.05 ; * * \mathrm{p}<.01$ & & & & &
\end{tabular}

\section{Conclusion}

As a descriptive study, it was tried to find out demographic characteristics and media usage level of digital tv platform adopters and non-adopter in Turkey. Young people are more disposed to adopt new technologies than elders (Bjoerner, 2003, p.94). Bjoerner (2003, p.94) argues that age and sex are important variables for adopting new technologies. Males are more disposed to adopt new technologies than females. On the contrary of Bjoerner findings, it's was not found any differences between adopters and non-adopters according to the age and sex in this study.

On the other hand, parallel to the literature, this study found that adopters are more educated and have more income than non-adopters. Studies about adopting rate argue that more educated people and people who have high income adopt new technologies faster than other (Chan-Olmsted at al., 2005, p.328). Education is important variable to understand messages which were sent via mass communication vehicles. The variables which affect awareness level of innovation are the usage of different communication medium, income and sex (Atkin at al. 2003, p.161). In addition these variables, in this study, number of household member and child number were found as variables which affect adopting level. Less people are living in the adopters' household and adopters have fewer children than non-adopters. According to the Svennevig's study (2004, p.157) people are viewing TV 4 hour in a day. This TV viewing time is higher than any 
Yersel, B. (2019). Adoption factors to digital TV platforms in Turkey. Journal of Human Sciences, 16(2), 469-476. doi:10.14687/jhs.v16i2.5696

other activities time such as conversation with friends, eating foods, doing house works, reading, and shopping. In addition TV viewing time is higher than other communication vehicles exposure. Findings of this study does not support Svennevig's finding about TV viewing. On the other hand adopters use more internet and read magazine and newspaper than the non-adopters. 5 factors effecting the adoption to digital tv platform.

In this study, five adopter categories of Rogers were coded as adopters and non-adopters and analyses based on these two categories. Rogers' five adopter categories should be investigated in the further research.

\section{References}

Atkin, David J., Kim Neuendorf, Leo W. Jefress and Paul Skalski "Predictors of Audience Interest in Adopting Digital Television". The Journal of Media Economics, 16 (3), 2003, 159-173.

Bagozzi, Richard P. and Yi, Youjae. "On the Evaluation of Structural Equations Models". Academy of Marketing Science Journal 16 (1): 74-94. 1988

Bjoerner, Thomas. "The Early Interactive Audience of a Regional TV-Station (DVB-T) in Denmark", Proceedings of the 1st European Conference on Interactive Television: From Viewers to Actors?, U.K:Brighton, 2003, 91-97.

Büyüköztürk, Şener, Sosyal Bilimler için Veri Analizi El Kitabı. Ankara: Pagem Yayıncılık, 2002.

Chan-Olmsted, Sylvia M., Jack C.C. Li and Jaemin Jung "The Profiling of Cable Modem Broadband Consumers: Characteristics, Perceptions and Satisfaction", Journal of Targeting Measurement and Analysis for Marketing, 13 (4), 2005, 327-345.

Child, Dennis. The Essentials of Factor Analysis. London: Holt, Rhinehart and Winston, 1970.

Dupagne, Michel. "Exploring the Characteristics of Potential High Definition Television Adopters", The Journal of Media Economics, 12 (1), 1999, 35-50.

Fidler, Roger. Understanding New Media, California: Pine Forge Press, 1997.

Jensen, Jens F. "So, What Do You Think, Linda? Media Typologies for Interactive Television". In Agger, G. and Jensen, J. F. eds. The Aesthetic of Television, Media \& Cultural Studies 2, Aalborg: Aalborg University Press. 2001, 349-396.

Hair, J., Anderson, R., Tatham, R. and Black, W. (1998) Multivariate Data Analysis. 5th Edition, Prentice Hall International, London.

Kalaycı, Şeref. SPSS Uygulamalı Çok Değişkenli İstatistik Teknikleri. Ankara: Asil Yayınları, 2006.

Kang, Myung-Hyun. "Digital Cable: Exploring Factors Associated with Early Adoption", Journal of Media Economics, 15 (3), 2002, 193-207.

Mahler, Alwin and Everett M. Rogers. "The Diffusion of Interactive Communications and the Critical Mass: The Adoption of Telecommunications Services By German Banks" Telecommunications Policy, 23 (10\&11), 1999, 719-740.

Mutlu, Erol, Communication Dictionary, Ankara: Ark, 1998

Rogers, Everett M. Diffusion of Innovations, U.S.A.: Free Press, 2003

Rose, Nancy L., and Paul L. Joskow "The Diffusion of New Technologies: Evidence from the Electric Utility Industry", Journal of Economics, 21 (3), 1990, 354-373.

Svennevig, Michael. "The Interactive Viewer: Reality or Myth", Interactive Marketing, 6 (2), 2004, 151-164.

Swedlow, Tracy. (2006). "2000: Interactive Enhanced Television: A Historical and Critical Perspective", http://www.itvt.com/etvwhitepaper.html (accessed, 13.3.2006).

Şencan, Hüner.(2005) Güvenilirlik ve geçerlilik. Ankara:Seçkin Yayınevi

Türkiye'nin dijital gözü araştırması (2018) available at online https://www.twentify.com/ (February, 2019) 